\title{
A comparative Study on the Propagation of Some Imported Peach Rootstocks by Using Hardwood Cuttings
}

\author{
Galal I. Eliwa*, Shaymaa N. Sayed**, Naguib S. Guirguis** and M. M. Wahba** \\ *Pomology Department, Faculty of Agriculture, Damietta University, Damietta, Egypt. \\ **Horticulture Research Institute, Agriculture Research Centre, Egypt.
}

\section{Received: $6 / 9 / 2018$}

\begin{abstract}
The present investigation was conducted during two successive seasons (2015/2016 and 2016/2017) to study the effects of hardwood cuttings collecting dates treated with indole-3-butyric acid (IBA), i.e. 0, 200 (24 h soaking) and $2000 \mathrm{ppm}$ ( $1 \mathrm{~min}$. dipping) on \%rooted cuttings, average number of roots/cutting, average length of roots/cutting $(\mathrm{cm})$, average root length/cutting $(\mathrm{cm})$ and $\%$ survival of rooted cuttings of peach [Prunus persica (L.) Batsch] rootstocks viz. Cadaman, Nemaguard, Okinawa and Nemaredunder greenhouse conditions. The effect of cutting collection dates on cuttings total indoles, total phenols and total indoles/total phenols ratio, total carbohydrates, total nitrogen and $\mathrm{C} / \mathrm{N}$ ratio, was also studied. The best date for collecting hardwood cuttings was the first of December since the mature shoots of the rootstocks contained the highest values of total indoles, total phenols and total carbohydrates and the lowest value of total nitrogen. The rooting potential of cuttings was positively correlated with their content of total indoles, total phenols, total indoles/total phenols ratio, total carbohydrate and C:N ratio, while had negative correlation with their content of total nitrogen.

The capacity of hardwood cuttings to develop adventitious roots varies among the rootstocks and between the IBA treatments. IBA at $2000 \mathrm{ppm}$ recorded the highest values of $\%$ rooted cuttings $(75.37$ and $73.01 \%)$, and \% survival of rooted cuttings (74.83 and $69.38 \%$ ) for Cadaman, while IBA at 200ppm was more effective in \% rooted cuttings (69.18 and $64.39 \%$ ), av. No. of roots/cutting (16.67 and 15.17), average length of roots/cutting $(57.72$ and $50.57 \mathrm{~cm})$, av. root length/cutting ( 3.48 and $3.41 \mathrm{~cm}$ ) and \% survival of rooted cuttings $(65.84$ and $63.48 \%)$ for Okinawa (as the mean of two dates during the two seasons of study respectively). Nemaguard recorded the lowest values in \% Rooted cuttings and \% Survival, while Nemared recorded moderate values in these respects. This study demonstrated the possibility propagation of imported peach rootstocks "Cadaman, Nemaguard, Okinawa and Nemared" locally by using hardwood cuttings to limit import from abroad and save hard currency for the country.
\end{abstract}

Keywords: peach, hardwood cutting, IBA, rooted cutting, survival.

\section{INTRODUCTION}

Peach [Prunus persica (L.) Batsch] is the most important stone fruit trees grown in Egypt. According to the FAO statistical data in year 2016, the total harvested area of peaches reached $20584 \mathrm{Hectares}$ (one feddan= $0.42 \mathrm{ha}$ ) with total production of about 266628 tons. (FAOSTAT, 2016). Root-knot nematodes ( $M$. incognita and $M$. javanica) have historically been the predominant species of root-knot nematodes. However, root-knot nematodes are a major problem and can limit expansion of peach growing in different areas in Egypt especially in sandy soil. So, most of peach orchards were grafted on Nemaguard rootstock because its rootknot nematode resistant.

The most common method to propagate peach rootstocks worldwide is by seed germination. Availability of seeds, less labor needed, and economics are the main advantages compared to vegetative propagation methods (Layne, 1987; Loreti and Morini, 2008). However, Seedling rootstocks often lack homogeneity because of outcrossing can occur in peach orchards, reaching up to $33 \%$ depending upon several biotic and abiotic conditions. This means that openpollinated peach seed cannot be assumed to be selfpollinated if the seed orchard contains several genotypes (Miller et al., 1989). Thus, like for scions, it is desirable to propagate rootstocks by a vegetative method in order to preserve the genetic characteristics of the original rootstock cultivar.

Corresponding author e-mail: geliwa2002@du.edu.eg
In Europe, there has already been an increasing trend to replace peach seedlings with clonal rootstocks, especially due to the advances in tissue culture and other vegetative methods (Loreti and Massai, 2002). Clonal Prunus genotypes have been tested around the world and released as rootstocks during the past six decades, but they all had to be screened first for ease of vegetative propagation (Reighard and Loreti, 2008).

Propagation from cuttings (cloning) produces a plant with the same characteristics as the parent and thus maintains desirable fruiting traits. In comparison with other types of cuttings (semi-hardwood, softwood and so on), hardwood cuttings are easy to take, handle and store which allows flexibility in the preparation of the cutting and, in general, less precision than cuttings that include actively growing tissue (Hartmann et al., 2002).

The date of the cuttings collection is very important, because the phenological state of the stock plants has an influence on rooting (Loretti et al., 1985). Endogenous content of sugars, sucrose, starch, indol-3acetic acid (IAA) and abscisic acid (ABA) in peach shoots also changes during the year and can influence rooting on cuttings (El-Boray et al., 1995; Tsipouridis et a.l, 2006).According to Howard (1987) and Szecskó et al. (2002), the best time for collecting plum cuttings is the fall. Although rooting percentage was increased when cuttings were collected from October to January (Eliwa, 1994; El-Boray et al., 1995; Loreti\&Morini, 2008; Nečas et al., 2016). 
Auxin treatments are commonly used in plant propagation to increase rooting percentages, hasten root initiation, increase the number and quality of roots, and encourage uniformity of rooting (El-Boray et al., 1995; Blythe et al., 2007). Moreover, Indole-3-butyric acid considered to be a well-accepted rooting auxin in cuttings, because it is nontoxic to plants over a wide concentration range and is effective in promoting rooting of a large number of plant species (Hartmann and Kester, 1990; Eliwa, 1994; El-Boray et al., 1995; Biasi et al., 2000; Rufato et al., 2000; Mayer el al., 2015).

Cadaman has introduced to Egypt via ElMaghraby Company from Italy as tissue culture seedlings in 2013. Also, Egypt is importing Nemagaurd, Okinawa and Nemared seeds from USA, Italy, Spain and France via the privet sector every year which cost many million dollars yearly.

The objectives of this study were to increase the percentage of hardwood cuttings of Cadaman, Nemagaurd, Okinawa and Nemared peach rootstocks that form roots by treating their cuttings with IBA, to hasten root initiation, increase the number and quality of roots per cutting and rise the survival percentage of rooted cuttings. Also, to find the time or period when the percent of rooted cuttings is maximal.

\section{MATERIALS AND METHODS}

Plant material: The present investigation was conducted during two successive seasons (2015/2016 and 2016/2017) as a trial to propagate four imported peach (Prunus persica (L.) Batsch) rootstocks (Cadaman, Nemaguard, Okinawa and Nemared) by using hardwood cuttings and to find the time or period when the percent of rooted cuttings is maximal.

The mother plants of these rootstocks were 3-5 old-years and free from diseases, growing in loamy soil in the farm of Horticulture Research Institute, Agriculture Research Center (ARC), Egypt.

Experimental methods: During both seasons of study, the hardwood cuttings $(18-22 \mathrm{~cm}$ length and $0.8-1.1 \mathrm{~cm}$ diameter, with normally spaced internodes having 6-7 buds) were prepared from sub-terminal part of one year-old shoots at two dates (first of December and first of January). The basal portion of cuttings was dipped in benlate (Fungicide) at $1 \mathrm{~g} / \mathrm{L}$. then treated with one of the following treatments: -

a) Dipping in IBA at $2000 \mathrm{ppm}$ for $1 \mathrm{~min}$.

b) Soaking in IBA at $200 \mathrm{ppm}$ for 24 hours.

c) Soaking in tap water for 24 hours (control).

The treated cuttings were placed in polyethylene bags filled with moist peat moss and stored in the refrigerator at $2-4^{\circ} \mathrm{C}$ for a month, then planted in plastic boxes $(53 \times 26 \times 6.5 \mathrm{~cm})$ filled with a mixture of peat moss, clean sand and vermiculite $(1: 1: 1 \mathrm{v} / \mathrm{v})$ treated with benlate (Fungicide) (1 $\mathrm{g} / \mathrm{kg}$ mixture). The plastic boxes Kept in the greenhouse, maintained bottom heat at $18-21^{\circ} \mathrm{C}$ and irrigated with mist irrigation $(15 \mathrm{~s} / 6 \mathrm{~min})$.

The experiment was laid out in a Split-Split-Plot Design with three replications and 30 cuttings per replication planted in one plastic box $(53 \times 26 \times 6,5$ $\mathrm{cm})$. Main plots consisted of two cuttings collecting dates $\left(1^{\text {st }}\right.$ Dec. and $1^{\text {st }}$ Jan.), sup-plots consisted of the four peach rootstocks (Cadaman, Nemaguard, Okinawa and Nemared) and sub-subplots consisted of three IBA concentrations $(0,200,2000 \mathrm{ppm})$.

\section{Chemical determination in mature shoots at collecting dates of hardwood cuttings}

A fresh sample from sub-terminal position of one-year old shoots were taken at the collecting dates $\left(1^{\text {st }}\right.$ Dec. and $1^{\text {st }}$ Jan.) of cuttings to determine total indoles and total soluble phenols. In this respect, twenty grams of fresh segments were weighted and blended for a constant time (3min) in $50 \mathrm{ml}$ methyl alcohol $80 \%$, then transferred quantitively into beakers covered with petri dishes, and immediately placed in the refrigerator for 24 hours. The same material was extracted twice using $80 \%$ methanolic solution according to Badr et al., (1971).

The crude extraction for each sample collected together, evaporated at $40^{\circ} \mathrm{C}$ under vacuum till complete dryness, and then dissolved in $80 \%$ methanol and filtrated through watman No. 50 . The filtrate was raised to $100 \mathrm{ml}$ with $80 \%$ methanol and kept in dark vials in refrigerator for quantitative determinations.

Total indoles: Total indoles were estimated calorimetrically by using P. dimethylamino benzaldehyde (Ehritch reagent) at $530 \mathrm{~nm}$ according to Larsen et al. (1962). The concentration of total indoles was calculated using a stander curve of indole acetic acid as mg per g. dry weight.

Total phenols: Total phenols were determined using the Folin Dennis colorimetric method (A.0.A.C., 1970) at $730 \mathrm{~nm}$. The concentration of total phenols was calculated using a standard curve of pyrogallol as $\mathrm{mg}$ per g. dry weight.

Total carbohydrates: Also, similar samples were dried at $70^{\circ} \mathrm{C}$ and grounded to determine the total carbohydrates and total nitrogen. For total carbohydrates, $0.2 \mathrm{gm}$ of dried sample was hydrolyzed with sulphuric acid, filtrated then $1 \mathrm{ml}$ of $5 \%$ phenol solution and $5 \mathrm{ml}$ sulphuric acid was added and calorimetrically determined using spectrophotometer at $490 \mathrm{~nm}$ according to Smith et al. (1956).

Total nitrogen:

For total nitrogen, $0.2 \mathrm{gm}$ powder of dried samples was digested to determine total nitrogen by using Micro-Kjeldahl method as described by Pregl (1945).

In addition, carbohydrate / nitrogen as well as indoles / phenols ratios were calculated and recorded.

\section{Rooting potentiality}

$\%$ Rooted cuttings: After two months from planting date, rooting potentiality was subjected for different treatments by checking 15 planted cuttings per replicate, then the rooting percentage was calculated according to the following equation: -

Rooting $\%=($ No of rooted cuttings) $/$ (No of checked up cuttings) $\times 100$

Average number of roots per rooted cutting: Roots directly arising from the lower parts of the cuttings were counted and average number of roots was calculated. Average length of roots per rooted cutting: The length of individual root on each rooted cutting was measured 
with the help of a thin flexible wire and a measuring scale. The average root length was calculated out and expressed in centimeters $(\mathrm{cm})$.

\%survival of rooted cuttings:

At the end of the growing season, at the first of December, number of survived rooted cuttings were counted, then the percentage of survival was calculated as following: -

Survival $\%=($ No of well-established cuttings $) /$ (No of remained cuttings) $\times 100$

\section{Statistical analysis:}

The data were statistically analyzed as a factorial experiment in completely randomized design with three replicates by analysis of variance (ANOVA) using the statistical package software SAS (SAS Institute Inc., 2000, Cary, NC. ‘ USA). Comparisons between means were made by using Duncan's multiple range test at $5 \%$ significance level (Duncan, 1955).

\section{RESULTS AND DISCUSSION}

Chemical content in mature shoots at collecting dates of hardwood cuttings

Total indoles and total phenols (mg/g DW): Data represented in Table (1) revealed that shoot peach rootstocks under this study were significantly deferred in their content of total indoles $(\mathrm{mg} / \mathrm{g} \mathrm{DW})$ between of them and at the dates of hardwood cuttings collection during the two seasons of study. In both the years under study, maximum mean of total indoles content has been recorded in Okinawa rootstock $(0.232 \mathrm{mg} / \mathrm{g} \mathrm{DW})$ in the first year and $(0.303 \mathrm{mg} / \mathrm{g} \mathrm{DW})$ in the second year followed by Cadaman rootstock. Meanwhile, the minimum mean of total indoles has been recorded in Nemaguard rootstock shoots $(0.048 \mathrm{mg} / \mathrm{g} \mathrm{DW})$ in the first year and $(0.154 \mathrm{mg} / \mathrm{g} \mathrm{DW})$ in the second year which is significantly different from other rootstocks under study. Also, in both the dates $\left(1^{\text {st }}\right.$ December and $1^{\text {st }}$ January) under study the mean of the values were greatly significant differed. Since, the maximum mean of total indoles contents has been recorded in the first date $\left(1^{\text {st }}\right.$ December $)$ which recorded $(0.167$ and 0.261 $\mathrm{mg} / \mathrm{g} \mathrm{DW})$ in the first and second season respectively. Whereas, the minimum values in this respect were recorded in the second date ( $1^{\text {st }}$ January) which recorded $(0.091$ and $0.191 \mathrm{mg} / \mathrm{g} \mathrm{DW})$ in the first and second year respectively. For the interaction, the values significantly varied between the rootstocks and the dates of hardwood cuttings collections. Since, the highest value was recorded for Okinawa rootstock $(0.329$ and 0.315 $\mathrm{mg} / \mathrm{g} \mathrm{DW})$ in the first date of cuttings collection $\left(1^{\mathrm{st}}\right.$ December) during the two seasons respectively followed by Cadaman rootstock $(0.176$ and $0.301 \mathrm{mg} / \mathrm{g}$ DW). Meanwhile, the lowest value was recorded for Nemaguard rootstock $(0.041 \mathrm{mg} / \mathrm{g} \mathrm{DW})$ in the first date of collected cuttings during 2015/2016 season.

The same trend was noticed with the mature shoot of peach rootstocks content of total phenols (Table 1). The rootstocks under this study were significantly deferred in their content of total phenols (as mg/ $\mathrm{g}$ dray weight) between of them and at the dates of hardwood cuttings collection during the two seasons of study. In both two years under study, maximum mean of total phenols content has been recorded for Okinawa rootstock to the extent of $(4.412 \mathrm{mg} / \mathrm{g} \mathrm{DW})$ in the first year and $(2.545 \mathrm{mg} / \mathrm{g} \mathrm{DW})$ in the second year. Meanwhile, the minimum value of total phenols has been recorded for Nemared rootstock shoots to the extent of $(2.632(\mathrm{mg} / \mathrm{g} \mathrm{DW})$ in the first year and $(2.128$ $\mathrm{mg} / \mathrm{g} \mathrm{DW}$ ) in the second year which is significantly different from other rootstocks under study. Also, in both the dates $\left(1^{\text {st }}\right.$ December and $1^{\text {st }}$ January) under study the mean of the values was greatly significant differed. The maximum mean of total phenols contents has been recorded in the second date ( $1^{\text {st }}$ January) which record $(3.335 \mathrm{mg} / \mathrm{g} \mathrm{DW})$ in the first year but it was lowest $(2.201 \mathrm{mg} / \mathrm{g}$ DW) in the second season, respectively. For the interaction, the values significantly deferred between the rootstocks and the dates of hardwood cuttings collections. The highest values were recorded for Okinawa rootstock (4.283 and $4.541 \mathrm{mg} / \mathrm{g}$ DW) in the first and second date, respectively during the first year of study followed by Cadaman rootstock. Meanwhile, the lowest value was recorded for Nemaguard rootstock $(1.791 \mathrm{mg} / \mathrm{g} \mathrm{DW})$ in the second date of collection cuttings during the second year of study.

In regard to total indoles and total phenols ratio, it was clear from (Table 1) that the rootstocks under this study were significantly deferred between of them and at the dates of hardwood cuttings collection during the two years of study. In both the two years under study, maximum mean of total indoles/total phenols ratio has been recorded in Okinawa rootstock $(0,052$ and 0,119$)$ in the first year and second year, respectively. Meanwhile, the minimum mean of total indoles/total phenols ratio has been recorded in Nemaguard rootstock (0.015 and 0.069) respectively during the two years of study. For the interaction, the values significantly deferred between the rootstocks and the dates of hardwood cuttings collections. The highest value was recorded for Cadaman rootstock $(0.130$ in the first date) followed by Okinawa rootstock $(0.121$ in the second date) during the second year of study. We have found similar results in the literature, with cuttings of cultivars with lower IAA-oxidase activity (which is mostly due to peroxidases) rooting better (Guskov et al., 1988). However, evidence for the contrary also can be found (Ryugo and Breen, 1974). Many authors examined the role of phenolics in rooting (Wilson and Van Staden 1990; Hartman and Kester, 1997), often getting correlations between the amount of phenolics and the rate of rooting (Rana and Chadha, 1992; Szecskó et al., 2007). Some phenolics preserve auxin from degradation by blocking the IAA-oxidase (peroxidase), on a way that peroxidases oxidize these phenolics instead, and auxin only later (Jarvis 1989). 
Table (1): Total indoles, total phenols contents and total indoles / total phenols ratio in mature shoots at collecting dates of hardwood cuttings of Cadaman, Nemaguard, Okinawa and Nemared peach rootstocks during 2015/2016 and 2016/2017 seasons

\begin{tabular}{|c|c|c|c|c|c|c|c|c|c|}
\hline \multirow[b]{2}{*}{ Rootstocks } & \multicolumn{3}{|c|}{$\begin{array}{c}\text { Total indoles } \\
(\mathrm{mg} / \mathrm{g} \mathrm{DW})\end{array}$} & \multicolumn{3}{|c|}{$\begin{array}{c}\text { Total phenols } \\
(\mathrm{mg} / \mathrm{g} \mathrm{DW})\end{array}$} & \multicolumn{3}{|c|}{$\begin{array}{c}\text { Total indoles /Total phenols } \\
\text { ratio }\end{array}$} \\
\hline & $1^{\text {st }}$ Dec. & $1^{\text {st }}$ Jun. & Mean & $1^{\text {st }}$ Dec. & $1^{\text {st }}$ Jun. & Mean & $1^{\text {st }}$ Dec. & $\mathbf{1}^{\text {st }}$ Jun. & Mean \\
\hline \multicolumn{10}{|c|}{ Season of $2015 / 2016$} \\
\hline Cadaman & $0.176 b$ & $0.105 b$ & $0.141 b$ & $3.013 \mathrm{~b}$ & $2.252 \mathrm{~d}$ & $2.805 \mathrm{c}$ & $0.058 \mathrm{~b}$ & $0.047 \mathrm{a}$ & $0.053 \mathrm{a}$ \\
\hline Nemaguard & $0.041 \mathrm{~d}$ & $0.055 \mathrm{~d}$ & $0.048 \mathrm{~d}$ & $2.923 \mathrm{c}$ & $3.310 \mathrm{~b}$ & $3.117 \mathrm{~b}$ & $0.014 d$ & $0.017 \mathrm{~d}$ & $0.015 \mathrm{~d}$ \\
\hline Okinawa & $0.329 \mathrm{a}$ & $0.134 \mathrm{a}$ & $0.232 \mathrm{a}$ & $4.283 \mathrm{a}$ & $4.541 \mathrm{a}$ & $4.412 \mathrm{a}$ & $0.076 \mathrm{a}$ & $0.029 b$ & $0.052 b$ \\
\hline Nemared & $0.123 \mathrm{c}$ & $0.068 \mathrm{c}$ & $0.096 \mathrm{c}$ & $2.371 \mathrm{~d}$ & $3.239 \mathrm{c}$ & $2.632 \mathrm{~d}$ & $0.052 \mathrm{c}$ & $0.021 \mathrm{e}$ & $0.034 \mathrm{c}$ \\
\hline Mean & $0.167 \mathrm{~A}$ & $0.091 \mathrm{~B}$ & & $3.148 \mathrm{~B}$ & $3.335 \mathrm{~A}$ & & $0.050 \mathrm{~A}$ & $0.029 \mathrm{~B}$ & \\
\hline \multicolumn{10}{|c|}{ Season of $2016 / 2017$} \\
\hline Cadaman & $0.301 b$ & $0.240 \mathrm{~b}$ & $0.271 b$ & $2.312 \mathrm{c}$ & $2.454 a$ & $2.388 b$ & $0.130 \mathrm{a}$ & $0.098 \mathrm{~b}$ & $0.114 b$ \\
\hline Nemaguard & $0.214 \mathrm{c}$ & $0.093 \mathrm{~d}$ & $0.154 d$ & $2.490 \mathrm{~b}$ & $1.791 \mathrm{~d}$ & $2.141 \mathrm{c}$ & $0.086 \mathrm{~d}$ & $0.052 \mathrm{~d}$ & $0.069 \mathrm{~d}$ \\
\hline Okinawa & $0.315 \mathrm{a}$ & $0.290 \mathrm{a}$ & $0.303 \mathrm{a}$ & $2.700 \mathrm{a}$ & $2.390 \mathrm{~b}$ & $2.545 \mathrm{a}$ & $0.117 b$ & $0.121 \mathrm{a}$ & $0.119 a$ \\
\hline Nemared & $0.214 \mathrm{c}$ & $0.141 \mathrm{c}$ & $0.178 \mathrm{c}$ & $2.085 \mathrm{~d}$ & $2.170 \mathrm{c}$ & $2.128 \mathrm{~d}$ & $0.102 \mathrm{c}$ & $0.065 \mathrm{c}$ & $0.084 \mathrm{c}$ \\
\hline Mean & $0.261 \mathrm{~A}$ & $0.191 \mathrm{~B}$ & & $2.588 \mathrm{~A}$ & $2.201 \mathrm{~B}$ & & $0.109 \mathrm{~A}$ & $0.084 \mathrm{~B}$ & \\
\hline
\end{tabular}

Total carbohydrate and nitrogen contents $(\mathrm{mg} / \mathrm{g}$ DW): It is clear from the data in Table (2) that mature shoots peach rootstocks under this study were significantly deferred in their content of total carbohydrate (as $\mathrm{mg} / \mathrm{g}$ dry weight) between the rootstocks and at the dates of hardwood cuttings collections during the two seasons of study. Regarding to the rootstocks, maximum mean of total carbohydrate content has been recorded in Okinawa rootstock (28.86) in the second year followed by Nemared rootstock (28.66). Meanwhile, the minimum value of total carbohydrate has been recorded in Nemaguard rootstock (27.32) in the second year which is significantly different from other rootstocks under study. Also, in both the dates $\left(1^{\text {st }}\right.$ December and $1^{\text {st }}$ January) the mean of the values were significant differed. Since, the maximum mean of total carbohydrate contents has been recorded in the second date ( $1^{\text {st }}$ January) which recorded (28.42 and 28.73) in the first and second year, respectively. Whereas, the minimum values in this respect were recorded in the first date $\left(1^{\text {st }}\right.$ December $)$ which recorded (28.35 and 28.00) in the first and second year respectively. For the interaction, the values significantly varied between the rootstocks and the dates of hardwood cuttings collection. Since, the highest value was recorded in Okinawa rootstock (28.86) in the two dates of cuttings collection during the second season. Meanwhile, the lowest value was recorded in Nemaguard rootstock (27.98 and 25.91) in the first date of collected cuttings during the two years of study, respectively. Also, mature shoots of peach rootstocks under this study were significantly deferred in their content of total nitrogen (as $\mathrm{mg} / \mathrm{g}$ dray weight) between of them and at the dates of hardwood cuttings collections during the two seasons of study (Table, 2). For the rootstocks, maximum mean of total nitrogen content has been recorded in Nemaguard rootstock (2.20 and 2.35) in the first and second year respectively. Meanwhile, the lowest mean of total nitrogen has been recorded in Cadaman rootstock (1.83) in the first year which is significantly different from other rootstocks under study. Also, in both the dates $\left(1^{\text {st }}\right.$ December and $1^{\text {st }}$ January) under study the mean of the values was significantly differed. Since, the maximum mean of total nitrogen contents has been recorded in the second date ( $1^{\text {st }}$ January) which recorded (2.05 and 2.32) in the first and second season, respectively. Whereas, the minimum means in this respect were recorded in the first date $\left(1^{\text {st }}\right.$ December) which recorded 1.93 and 2.15$)$ in the first and second year respectively. For the interaction, the values significantly varied between the rootstocks and the dates of hardwood cuttings collection. The highest value was recorded in Nemaguard rootstock (2.43) in the second date of cuttings collection during the second season. Meanwhile, the lowest value was recorded in Okinawa rootstock (1.81) in the first date of collection cuttings during the first year of study.

It was clear from the data illustrated in (Table 2) that the rootstocks under this study were significantly deferred in this respect between of them and at the dates of hardwood cuttings collection during the two seasons of study. For the rootstocks under study, maximum mean of $\mathrm{C} / \mathrm{N}$ ratio has been recorded in Okinawa rootstock (15.52 and 13.73) in the first year and second year respectively. Meanwhile, the minimum value of $\mathrm{C} / \mathrm{N}$ ratio has been recorded in Nemared rootstock (13.06 and 11.63) during the two years of study respectively. For the interaction, the values significantly deferred between the rootstocks and the dates of hardwood cuttings collection. Since, the highest value was recorded in Okenawa rootstock (15.65 and 15.38) followed statistically by Cadaman rootstock (15.35 and 14.14 ) in the first and second date respectively during the first year of study. Similar results were reported in the literature, the date of the cuttings collection is very important, because the phenological state of the stock plants has an influence on rooting (Loretti et al., 1985). Endogenous content of sugars, sucrose, starch, indol-3acetic acid (IAA) and abscisic acid (ABA) in peach shoots also changes during the year and can influence rooting on cuttings (El-Boray et al., 1995; Tsipouridis et al., 2006). Szecskó et al. (2007) concluded that the complex process of rooting can be influenced in direct or indirect ways by the factors under investigation. According to Howard (1987) and Szecskó et al. (2002), 
the best time for collecting plum cuttings is the fall. While rooting percentage is increased when cuttings are collected from October to January (El-Boray et al., 1995; Szecskó and Hrotkó, 2004; Loreti \& Morini, 2008; Nečas et al., 2016).

Sprouting: During both seasons of study, it was noticed that the extent and speed of the sprouting of observation was made cuttings planted under a greenhouse conditions (Table 1\&2). In spite of the rootstocks to differences in their chilling units $(\mathrm{CU})$ requirements, $150 \mathrm{CU}$ for Okinawa rootstock to $850 \mathrm{CU}$ for Nemaguard rootstock, all the rootstocks took the same duration in sprouting which extended 2-3 weeks for the two dates of cuttings collections and that is could be attributed to the cooled storage for the cuttings before planting in the refrigerator at $2-4^{\circ} \mathrm{C}$ for a month resulted in achieving the chilling units requirements of the rootstocks. The hardwood cutting treated with IBA took minimum duration in sprouting while it was longest for the control. These results were supported by Narayan et al. (2013) and Sukhjit Kaur, (2015) on peach.

Some researchers suggested that the presence of buds is essential for the formation of root initials (Hartmann et al., 1990). The buds produce some biochemical substances that have effect on root formation. These substances form only in active buds, but not during the endodormancy, when the rooting is minimal.

Table (2): Total carbohydrates, total nitrogen contents and $\mathrm{C} / \mathrm{N}$ ratio in mature shoots at collecting dates of hardwood cuttings of Cadaman, Nemaguard, Okinawa and Nemared peach rootstocks during 2015/2016 and 2016/2017 seasons

\begin{tabular}{|c|c|c|c|c|c|c|c|c|c|}
\hline \multirow[t]{2}{*}{ Rootstocks } & \multicolumn{3}{|c|}{$\begin{array}{c}\text { Total carbohydrate } \\
(\mathrm{mg} / \mathrm{g} \mathrm{DW})\end{array}$} & \multicolumn{3}{|c|}{$\begin{array}{c}\text { Total nitrogen } \\
(\mathrm{mg} / \mathrm{g} \mathrm{DW})\end{array}$} & \multicolumn{3}{|c|}{$\mathrm{C} / \mathrm{N}$ ratio } \\
\hline & $1^{\text {st }}$ Dec. & $1^{\text {st }}$ Jun. & Mean & $1^{\text {st }}$ Dec. & $\mathbf{1}^{\text {st }}$ Jun. & Mean & $1^{\text {st }}$ Dec. & $\mathbf{1}^{\text {st }}$ Jun. & Mean \\
\hline \multicolumn{10}{|c|}{ Season of $2015 / 2016$} \\
\hline Cadaman & $28.22 \mathrm{c}$ & $28.34 \mathrm{c}$ & $28.28 \mathrm{c}$ & $1.82 \mathrm{c}$ & $1.84 \mathrm{~d}$ & $1.83 \mathrm{~d}$ & $15.35 b$ & $14.14 b$ & $14.75 \mathrm{~b}$ \\
\hline Nemaguard & $27.98 \mathrm{~d}$ & $28.46 \mathrm{a}$ & $28.22 \mathrm{~d}$ & $2.15 \mathrm{a}$ & $2.24 \mathrm{a}$ & $2.20 \mathrm{a}$ & $13.42 d$ & $12.69 \mathrm{~d}$ & $13.06 \mathrm{~d}$ \\
\hline Okinawa & $28.34 b$ & $28.46 \mathrm{a}$ & $28.40 \mathrm{~b}$ & $1.81 \mathrm{~d}$ & $2.01 \mathrm{c}$ & $1.91 \mathrm{c}$ & $15.65 \mathrm{a}$ & $15.38 \mathrm{a}$ & $15.52 \mathrm{a}$ \\
\hline Nemared & $28.86 \mathrm{a}$ & $28.42 b$ & $28.63 \mathrm{a}$ & $1.96 \mathrm{~b}$ & $2.11 \mathrm{~b}$ & $2.03 \mathrm{~b}$ & $14.41 \mathrm{c}$ & $13.50 \mathrm{c}$ & $13.96 \mathrm{c}$ \\
\hline Mean & $28.35 \mathrm{~B}$ & $28.42 \mathrm{~A}$ & & $1.93 \mathrm{~B}$ & $2.05 \mathrm{~A}$ & & $14.73 \mathrm{~A}$ & $13.93 \mathrm{~B}$ & \\
\hline \multicolumn{10}{|c|}{ Season of $2016 / 2017$} \\
\hline Cadaman & $28.77 \mathrm{~b}$ & $28.46 \mathrm{c}$ & $28.61 \mathrm{c}$ & $2.22 \mathrm{~b}$ & $2.30 \mathrm{c}$ & $2.26 \mathrm{~b}$ & $13.02 \mathrm{c}$ & $12.49 b$ & $12.76 \mathrm{~b}$ \\
\hline Nemaguard & $25.91 d$ & $28.74 b$ & $27.32 d$ & $2.28 \mathrm{a}$ & $2.43 \mathrm{a}$ & $2.35 \mathrm{a}$ & $11.37 \mathrm{~d}$ & $11.88 \mathrm{~d}$ & $11.63 d$ \\
\hline Okinawa & $28.86 \mathrm{a}$ & $28.86 \mathrm{a}$ & $28.86 \mathrm{a}$ & $1.98 \mathrm{~d}$ & $2.20 \mathrm{~d}$ & $2.09 \mathrm{~d}$ & $14.55 \mathrm{a}$ & $12.91 \mathrm{a}$ & $13.73 \mathrm{a}$ \\
\hline Nemared & $28.46 \mathrm{c}$ & $28.86 \mathrm{a}$ & $28.66 \mathrm{~b}$ & $2.16 \mathrm{a}$ & $2.37 \mathrm{~b}$ & $2.26 \mathrm{~b}$ & $13.17 \mathrm{~b}$ & $12.17 \mathrm{c}$ & $12.67 \mathrm{c}$ \\
\hline Mean & $28.00 \mathrm{~B}$ & $28.73 \mathrm{~A}$ & & $2.15 \mathrm{~B}$ & $2.32 \mathrm{~A}$ & & $13.03 \mathrm{~A}$ & $12.36 \mathrm{~B}$ & \\
\hline
\end{tabular}

Rooting potentiality and \%Survival of rooted cuttings: Data recorded on \% rooted cuttings, average number of roots/cutting, average length of roots/cutting $(\mathrm{cm})$, average root length/cutting $(\mathrm{cm})$ and \%survival of rooted cuttings from hardwood cuttings of peach rootstocks under the study as affected by cuttings collection date and different IBA treatments are presented in Tables ( $3 \& 4)$.

In both seasons, mean percent rooted cuttings (Table 3\&4) shows significant differences among rootstocks being maximum in Cadaman $(75.37 \%$ in the first season and $73.1 \%$ in the second season) which is statistically at par with Okinawa $(69.18 \%$ and $68.31 \%$ during the two seasons, respectively). Meanwhile, the minimum mean percent recorded in Nemagured $(25.33 \%$ to $30.51 \%$ during the two seasons, respectively).As for the effect of collecting date on mean percent rooted cuttings (Table $3 \& 4$ ), data revealed significant differences between the two cuttings collecting dates under the study. Since the first date $\left(1^{\text {st }}\right.$ December) was higher $(39.30 \%$ in the first season and $37.47 \%$ in the second season) than the second date $\left(1^{\text {st }}\right.$ January) which recorded $34.61 \%$ in the first season and $35.99 \%$ in the second season. In the first season of study (Table 3), among the treatments higher mean percent rooted cuttings was observed as $75.37 \%$ upon treatment with 2000 ppm IBA for Cadaman which is statistically at par with $69.18 \%$ under 200 ppm IBA in Okinawa. Among interactions, maximum percent rooted cuttings $(84.07 \%)$ observed in Okinawa under 200 ppm IBA followed statistically $(73.91 \%)$ under $2000 \mathrm{ppm}$ IBA in Cadaman in the first date of cuttings collection and $76.52 \%$ under 2000 ppm IBA in Cadaman in the second date of cuttings collection followed statistically $64.78 \%$ under 200 ppm IBA in Cadaman in the second date of cuttings collection. In the second year of study (Table 4), among treatments higher mean percent rooted cuttings observed as $73.01 \%$ with $2000 \mathrm{ppm} \mathrm{IBA} \mathrm{in}$ Cadaman which is statistically at par with $68.31 \%$ under $2000 \mathrm{ppm}$ in Okenawa. Data reported herein were in agreement with several researchers whom obtained rooting in peach cuttings by applying IBA in concentrations from 500 to $2500 \mathrm{mg} / \mathrm{L}$ (Eliwa, 1994; ElBoray et al., 1995; Oliveira et al., 2003; Tsipouridis et al., 2003\&2005).

In the control treatments mean percent rooted cuttings was observed as $7.25 \%$ in Okenawa followed statistically $5.08 \%$ by Cadaman in the first season of study and was $6.66 \%$ for Okenawa followed statistically $4.46 \%$ by Cadaman in the second season of study. However, it was $0.00 \%$ in Nemaguard and Nemared during both seasons. Such character indicating the presence of naturally hormones in this rootstock was sufficient amount for root initiation. 
During this study, the rooting potential of cuttings was differed among the rootstocks and recorded a positively correlated with their content of total indoles, total phenols, total indoles/total phenols ratio carbohydrate and $\mathrm{C}: \mathrm{N}$ ratio, while had negative correlation with their content of total nitrogen (Table $1 \& 2)$. The phenomenon confirms the observations of Hess (1964) who obtained the highest amount of extractable root promoting co-factors in easy to root cuttings than in the difficult to root varieties of Chrysanthemum.

As for the effect of collecting date on mean average number of roots per cutting (Table 3 and 4), data revealed significant differences between the two cuttings collecting dates under the study. Since the first date $\left(1^{\text {st }}\right.$ December) was higher $(11.61)$ in the first season and in the second (9.36) season than the second date (1s January) which recorded 9.3 in the first season and 7.64 in the second season. During the first season of study (Table 3), among the treatments higher mean average number of roots per cutting was observed as 34.17 upon treatment with 200 ppm IBA in Cadaman which is followed statistically 16.67 under 200 ppm IBA in Okinawa. Among interactions, maximum average number of roots per cutting 35.67 observed in Cadaman under 200 ppm IBA followed statistically 22.33 under 200 ppm IBA in Nemagurd in the first date of cuttings collection. In the second year of study (Table 4 ), among treatments average number of roots per cutting observed as 20.33 with 200 ppm IBA in Cadaman which is statistically at par with 19.67 under 2000 ppm in Nemaguard.

Concerning average length of roots/cutting (cm) and average root length/cutting $(\mathrm{cm})$, took the same trend with average number of roots per cutting (Table 3\&4).

Table (3): Effect of IBA treatments on \% rooted cuttings, average roots number/cutting, average roots length/cutting, average root length/root and rooted cuttings survival \% at two cuttings collection dates of some peach rootstocks during 2015/2016 season

\begin{tabular}{|c|c|c|c|c|c|c|c|c|c|c|c|c|c|c|c|c|}
\hline \multirow[t]{2}{*}{ Rootstock } & \multirow{2}{*}{$\begin{array}{l}\text { IBA } \\
\text { ppm }\end{array}$} & \multicolumn{3}{|c|}{ \% Rooted cuttings } & \multicolumn{3}{|c|}{$\begin{array}{c}\text { Av. Roots } \\
\text { number/cutting }\end{array}$} & \multicolumn{3}{|c|}{$\begin{array}{l}\text { Av. Roots length/ } \\
\text { cutting (cm) }\end{array}$} & \multicolumn{3}{|c|}{$\begin{array}{l}\text { Av. Root length /root } \\
(\mathrm{cm})\end{array}$} & \multicolumn{3}{|c|}{$\begin{array}{l}\text { rooted cuttings } \\
\text { Survival } \%\end{array}$} \\
\hline & & $1^{\text {st }}$ Dec. & $1^{\text {st } J a n . ~}$ & Mean & $1^{\text {st }}$ Dec. & $1^{\text {st }}$ Jan. & Mean & $1^{\text {st }}$ Dec. & $1^{\text {st }}$ Jan. & Mean & $1^{\text {st }}$ Dec. & $1^{\text {st }}$ Jan. & Mean & $1^{\text {st }}$ Dec. & $1^{\text {st }}$ Jan. & Mean \\
\hline \multirow{3}{*}{ Cadaman } & & $5.88 \mathrm{e}$ & & & $2.00 \mathrm{~d}$ & $3.00 \mathrm{~cd}$ & $2.50 \mathrm{~d}$ & $6.25 \mathrm{~d}$ & & $8.51 \mathrm{de}$ & & $3.17 \mathrm{ab}$ & & $5.21 \mathrm{~g}$ & $4.28 \mathrm{~g}$ & $4.75 \mathrm{~h}$ \\
\hline & & $59.25 \mathrm{c}$ & $64.78 \mathrm{~b}$ & $.02 b$ & $35.67 \mathrm{a}$ & $32.67 \mathrm{a}$ & $34.17 \mathrm{a}$ & $82.00 \mathrm{a}$ & $80.67 \mathrm{a}$ & $81.33 \mathrm{a}$ & $2.38 \mathrm{a}-\mathrm{d}$ & 2.66abc & $2.52 \mathrm{~b}-\mathrm{e}$ & $59.25 \mathrm{~b}$ & $3.04 \mathrm{~b}$ & $61.15 \mathrm{bc}$ \\
\hline & & & & & $17.00 \mathrm{bcd}$ & & & $55.00 \mathrm{abc}$ & & $59.00 \mathrm{a}$ & & & & $73.91 \mathrm{a}$ & & $74.38 \mathrm{a}$ \\
\hline \multirow{3}{*}{ Nemaguard } & & 0 & & & $0.00 \mathrm{~d}$ & $0.00 \mathrm{~d}$ & & $0.00 \mathrm{~d}$ & & $0.00 \mathrm{e}$ & $.00 \mathrm{f}$ & & & $0.00 \mathrm{~h}$ & $0 \mathrm{~g}$ & $0.00 \mathrm{~h}$ \\
\hline & & $26.37 d$ & $24.28 \mathrm{~g}$ & $.33 \mathrm{~d}$ & $10.33 \mathrm{bcd}$ & $6.00 \mathrm{~cd}$ & $8.17 \mathrm{bcd}$ & $14.67 \mathrm{~cd}$ & 19.17 & $16.92 \mathrm{cde}$ & $1.32 \mathrm{de}$ & $.17 \mathrm{ab}$ & & $24.71 \mathrm{f}$ & $14.28 \mathrm{f}$ & $19.49 \mathrm{~g}$ \\
\hline & & $30.72 \mathrm{~d}$ & & & $22.33 \mathrm{ab}$ & $4.00 \mathrm{~cd}$ & 13. & $49.30 \mathrm{abc}$ & & $31.03 \mathrm{~cd}$ & $b-e$ & & & $30.72 \mathrm{e}$ & & $26.54 f$ \\
\hline \multirow{3}{*}{ Okinawa } & & $9.16 \mathrm{e}$ & & & $1.33 \mathrm{~d}$ & $1.67 \mathrm{~cd}$ & & $3.50 \mathrm{~d}$ & & $3.33 \mathrm{e}$ & & & & $3.83 \mathrm{gh}$ & & $3.89 \mathrm{~h}$ \\
\hline & & $84.07 \mathrm{a}$ & $54.28 \mathrm{~cd}$ & $69.18 \mathrm{a}$ & $19.00 \mathrm{bc}$ & $14.33 \mathrm{bc}$ & $16.67 \mathrm{~b}$ & $63.43 \mathrm{ab}$ & $52.00 \mathrm{abc}$ & $57.72 \mathrm{ab}$ & $3.43 \mathrm{a}$ & $3.53 \mathrm{a}$ & & $77.40 \mathrm{a}$ & $54.28 \mathrm{c}$ & $65.84 \mathrm{~b}$ \\
\hline & & $61.72 \mathrm{c}$ & $13 \mathrm{c}$ & $59.43 b$ & $3.00 \mathrm{~cd}$ & $4.67 \mathrm{~cd}$ & $3.83 \mathrm{~cd}$ & $4.00 \mathrm{~d}$ & $50 \mathrm{de}$ & $8.25 \mathrm{de}$ & $1.11 \mathrm{e}$ & $2.11 b c$ & $1 \mathrm{f}$ & $61.72 b$ & $53.80 \mathrm{c}$ & $57.76 \mathrm{~cd}$ \\
\hline \multirow{3}{*}{ Nemared } & & & & & $0.00 \mathrm{~d}$ & $0.00 \mathrm{~d}$ & & $0.00 \mathrm{~d}$ & & $.000 \mathrm{e}$ & & & & $0.00 \mathrm{~h}$ & & $0.00 \mathrm{~h}$ \\
\hline & & $57.61 \mathrm{c}$ & & & $15.00 \mathrm{bcd}$ & $3.67 \mathrm{~cd}$ & $9.33 \mathrm{bcd}$ & $23.00 \mathrm{~cd}$ & $6.17 \mathrm{e}$ & $14.58 \mathrm{cde}$ & $1.61 \mathrm{de}$ & 1.7 & $1.67 \mathrm{ef}$ & $47.61 \mathrm{~d}$ & $45.88 \mathrm{~d}$ & $46.74 \mathrm{e}$ \\
\hline & & $62.94 \mathrm{c}$ & & $8.23 \mathrm{bc}$ & $13.67 \mathrm{bcd}$ & $22.67 \mathrm{ab}$ & $18.17 \mathrm{~b}$ & $26.50 \mathrm{bcd}$ & & $34.75 \mathrm{bc}$ & & & $1.97 \mathrm{def}$ & $52.94 \mathrm{c}$ & & $53.23 \mathrm{~d}$ \\
\hline Meal & & 39.30A & 34.61B & ---- & $11.61 \mathrm{~A}$ & $9.3 \mathrm{~B}$ & ---- & $27.30 \mathrm{~A}$ & 25.27 B & --- & $1.91 \mathrm{~B}$ & $2.25 \mathrm{~A}$ & -- & 36.44A & 32.52B & -- \\
\hline
\end{tabular}

Table (4): Effect of IBA treatments on \% rooted cuttings, average roots number/cutting, average roots length/cutting, average root length/root and rooted cuttings survival \% at two cuttings collection dates of some peach rootstocks during 2016/2017 season

\begin{tabular}{|c|c|c|c|c|c|c|c|c|c|c|c|c|c|c|c|c|}
\hline \multirow[t]{2}{*}{ Rootstock } & \multirow[t]{2}{*}{ IBA ppm } & \multicolumn{3}{|c|}{$\%$ Rooted cuttings } & \multicolumn{3}{|c|}{$\begin{array}{c}\text { Av. Roots } \\
\text { number/cutting }\end{array}$} & \multicolumn{3}{|c|}{\begin{tabular}{|c|} 
Av. Roots length/ cutting \\
$(\mathrm{cm})$
\end{tabular}} & \multicolumn{3}{|c|}{$\begin{array}{l}\text { Av. Root length /root } \\
\text { (cm) }\end{array}$} & \multicolumn{3}{|c|}{$\begin{array}{c}\text { rooted cuttings Survival } \\
\%\end{array}$} \\
\hline & & $1^{\text {st }} \mathrm{Dec}$ & $1^{\text {st }}$ Jan. & Mean & $1^{\text {st }}$ Dec. & $1^{\text {st }}$ Jan. & Mean & $1^{\text {st }}$ Dec. & $1^{\text {st }}$ Jan. & Mean & $1^{\text {st }}$ Dec. & $1^{\text {st }}$ Jan. & Mean & $1^{\text {st }}$ Dec. & $1^{\text {st }}$ Jan. & Mean \\
\hline \multirow{3}{*}{ Cadaman } & & $3.51 \mathrm{ef}$ & & $.46 \mathrm{fg}$ & $1.00 \mathrm{c}$ & & $1.00 \mathrm{de}$ & $4.00 \mathrm{c}$ & & & & & & & $5.08 \mathrm{ff}$ & \\
\hline & & & & & & & & & & & & & & & & \\
\hline & & $71.58 \mathrm{a}$ & & & 15.3 & $16.00 \mathrm{ab}$ & 15.6 & $9.33 \mathrm{a}$ & & & & & & & & \\
\hline \multirow{3}{*}{ Nemaguard } & & $.00 \mathrm{f}$ & & & $0.00 \mathrm{c}$ & $00 \mathrm{~d}$ & 0.0 & $.00 \mathrm{c}$ & $00 \mathrm{f}$ & & $0.00 \mathrm{~d}$ & $.00 \mathrm{c}$ & & & $0.00 \mathrm{f}$ & $0 \mathrm{f}$ \\
\hline & & $27.41 \mathrm{~d}$ & 5 & & $9.00 \mathrm{bc}$ & & 7.6 & 26. & 26. & & 3.0 & & & & & \\
\hline & & $32.04 \mathrm{~d}$ & & & $19.67 \mathrm{a}$ & $9.00 \mathrm{~d}$ & $14.33 \mathrm{abc}$ & $57.27 \mathrm{a}$ & & & 2.9 & & & & $.99 \mathrm{e}$ & \\
\hline \multirow{3}{*}{ Okinawa } & & $6.66 \mathrm{e}$ & & & $1.67 \mathrm{c}$ & $1.00 \mathrm{~d}$ & $1.33 \mathrm{de}$ & $.33 \mathrm{c}$ & & & 1.3 & & & & $1.89 \mathrm{f}$ & \\
\hline & & $68.75 \mathrm{ab}$ & $0.04 \mathrm{~b}$ & $64.39 \mathrm{~b}$ & $17.33 \mathrm{ab}$ & $13.00 \mathrm{bc}$ & $15.17 \mathrm{ab}$ & $52.40 \mathrm{a}$ & $48.73 b c$ & & $3.05 \mathrm{~b}$ & 3.76 & $3.41 \mathrm{bc}$ & & $57.95 \mathrm{c}$ & $63.48 \mathrm{~b}$ \\
\hline & & $66.75 \mathrm{ab}$ & $69.86 \mathrm{a}$ & $68.31 \mathrm{ab}$ & $7.00 \mathrm{bc}$ & $7.00 \mathrm{bcd}$ & $7.00 \mathrm{cde}$ & $51.50 \mathrm{a}$ & $52.67 \mathrm{abc}$ & & $7.65 \mathrm{a}$ & & & & $59.86 \mathrm{~b}$ & $61 \mathrm{bc}$ \\
\hline \multirow{3}{*}{ Nemared } & & $0.00 \mathrm{f}$ & & & $0.00 \mathrm{c}$ & $0.00 \mathrm{~d}$ & $0.00 \mathrm{e}$ & $0.00 \mathrm{c}$ & $0.00 \mathrm{f}$ & & $0.00 \mathrm{~d}$ & $0.00 \mathrm{c}$ & & & $0.00 \mathrm{f}$ & \\
\hline & & $55.81 \mathrm{c}$ & $45.55 \mathrm{c}$ & $50.68 \mathrm{~d}$ & $11.00 \mathrm{bc}$ & $3.33 \mathrm{~cd}$ & $7.17 \mathrm{cde}$ & $30.47 b$ & $11.67 \mathrm{ef}$ & $21.07 \mathrm{c}$ & $2.69 \mathrm{bc}$ & $3.31 \mathrm{~b}$ & $3.00 \mathrm{c}$ & $53.77 \mathrm{c}$ & $45.55 \mathrm{~d}$ & $49.66 \mathrm{~d}$ \\
\hline & & $64.13 \mathrm{~b}$ & & $56.57 \mathrm{c}$ & $10.33 \mathrm{abc}$ & $14.67 \mathrm{ab}$ & $12.50 \mathrm{bc}$ & $32.60 \mathrm{~b}$ & $40.00 \mathrm{c}$ & $36.30 \mathrm{~b}$ & $3.11 \mathrm{~b}$ & $2.99 \mathrm{~b}$ & $3.05 \mathrm{c}$ & $60.80 \mathrm{~b}$ & $52.35 \mathrm{c}$ & $56.57 \mathrm{c}$ \\
\hline \multicolumn{2}{|c|}{ Mean } & $37.47 \mathrm{~A}$ & 35.99B & --- & $9.36 \mathrm{~A}$ & 7.64B & -- & 29.89A & 27.06B & -- & $2.56 \mathrm{~B}$ & $3.44 \mathrm{~A}$ & --- & $35.94 \mathrm{~A}$ & 34.16B & --- \\
\hline
\end{tabular}

Data in Table (3 \& 4) revealed significant differences among rootstocks and the maximum was in Cadaman $(74.38 \%$ in the first season and $69.38 \%$ in the second season) which is followed statistically by Okinawa $(65.84 \%$ and $63.48 \%$ during the two seasons, respectively).

As for the effect of collecting date on mean \% survival of rooted cuttings (Table $3 \& 4$ ), data showed significant differences between the two cuttings collecting dates under the study. The first date $\left(1^{\text {st }}\right.$ December) was higher $(36.44 \%$ in the first season and $35.94 \%$ in the second season) than the second date (1s January) which recorded $32.52 \%$ in the first season and $34.16 \%$ in the second season. In the first season (Table 3 ), among the treatments higher mean \%survival of rooted cuttings was observed as $74.38 \%$ upon treatment with 2000 ppm IBA in Cadaman which is followed statistically $65.48 \%$ under 200 ppm IBA in Okinawa. 
Among interactions, maximum percent survival rooted cuttings 77.40. \% observed in Okinawa under 200 ppm IBA which is statistically at par with $73.91 \%$ under 2000 ppm IBA in Cadaman in the first date of cuttings collection and $74.85 \%$ under 2000 ppm IBA in Cadaman in the second date of cuttings collection date. In the second season (Table 4), among treatments higher mean percent rooted cuttings observed as $69.38 \%$ with 2000 ppm IBA in Cadaman which is followed statistically by63.48\% under 200 ppm in Okenawa.

It was clear from the above-mentioned results that the collecting date of hardwood cuttings had a strong influence on rooting ability. Such effect could be attributed to the presence and rates of both root inhibitor and promoter substances (as indicated in Tables $1 \& 2$ ) which were greatly differed among the rootstocks and by cuttings collecting date.

The obtained results were in conformity of the previous findings as reported by Jauanda et al. (1979), in which they compared Flordasun and Matchless cultivars of peach and concluded that Flordasun rooted better than cv. Matchless when treated with $1000 \mathrm{ppm}$ IBA. Pervez et al. (2007) found that IBA concentrations .2000ppm IBA promoted early rooting, quick cell division as compared to other concentrations and hence, lengthy roots.

\section{CONCLUSION}

The results of the present investigation clearly indicated that the optimal time for collecting hardwood cuttings of peach rootstocks was the first of December. It could be recommend the use of IBA at the $200 \mathrm{ppm}$ (24 h soaking) or $2000 \mathrm{ppm}$ (1 min dipping) concentration and store in the refrigerator at $2-4^{\circ} \mathrm{C}$ for a month to increase the percentage of hardwood cuttings that form roots, hasten root initiation, increase number and quality of roots per cutting and rise the survival percentage of rooted cuttings of Cadaman, Nemagaurd, Okinawa and Nemared peach rootstocks. Propagation of such rootstocks by hardwood cuttings using IBA as rooting hormone can be a viable option and have commercially high value.

\section{REFERENCES}

A.0.A.C. (1970): Association of official agricultural chemists. Official methods of analysis. Washington D. C., USA, PP. 832.

Badr, S. A., G. C. Martin and H. T. Hartmann (1971): A modified method for extraction and identification of abscisic acid and gibberellinlike substances from the olive. Plant Physio., 24: 191-198.

Blythe, E.K., J. L. Sibley, K.M. Tilt and J.M. Ruter (2007). Methods of auxin application in cutting propagation: a review of 70 years of scientific discovery and commercial practice. J. Environ. Hort. 25(3):166-185.

Duncan, D. B. (1955). Multiple Range and Multiple ftest. Biometrics. 11: 1-42.
El-Boray, M. S., M.A. Iraqi, N.R. Samra and G. I. Eliwa (1995). Studies on rooting hardwood cuttings of MeitGhamr peach cultivar. J. Agric. Sci. Mansoura Univ. 20 (12): 5127 - 5127.

Eliwa, G. I. (1994). Physiological studies on peach trees. Ph. D. Thesis, Fac. Of Agric., Mansoura Univ.

FAO (2016). Food and Agriculture Organization. (http:// faostat. Fao.org).

Hartmann, H. T. and D. E. Kester (1997). Plant propagation. Principles and Practices. PrenticeHall, New Jersey.

Hartmann, H.T., D.E. Kester, F.T. Davis and R.L. Geneve (2002). Hartmann and Kesters' Plant Propagation:Princ. 7th Ed. Prentice Hall, Upper Saddle River, NJ.

Howard, B.H. (1987). Propagation. In: Rom, R.C. and Carlson, R.F. (eds.). Rootstocks for fruit crops. John Wiley and Sons, New York, p. 29-77.

Jauanda, J.S., J.S. Josan and S.N. Singh (1979) Propagation of prunus sp. by cutting (i) Effect of IBA and the type of peach cutting on rooting J. Res. India, 16 (4): 33-38.

Jarvis, B. C. (1986): Endogenous control of adventitious rooting in non-woody cuttings. In: JACKSON, M.B. (ed.): New root formation in plants and cuttings. Martinus Nijhoff Publishers, Dordrecht, 191-222.

Larsen, P., A. Harbo, S. Klungsour and T. Asheim (1962). The biogenesis of some indol compounds in Acetobacter xylinum. Physiol. Plant., 15:552-565.

Layne, R.E.C. (1987). Peach rootstocks. p. 185-216. In: R.C. Rom and R.F. Carlson (eds.), Rootstocks for fruit crops. John Wiley \& Sons.

Loreti, F. and R. Massai (2002): The high-density peach planting system: present status and perspectives. Acta Hort. 592:377-390.

Loreti, F. and S. Morini (2008). Propagation techniques. p. 221-243. In: D.R. Layne and D. Bassi (eds.), The Peach: Botany, Production and Uses. CABI, UK.

Loreti, F., S. Morini and A. Grilli (1985): Rooting response of 'P.S. B2' and 'GF 677' rootstock cuttings. Acta Hort. 173: 261-269.

Mayer, N. A.;Reighard, G. L.; Bridges, W. (2015):Peach Rootstock Propagation under Intermittent Mist System. Acta hortic. 1084: 53-61.

Miller, P.J., D.E. Parfitt and S.A. Weinbaum (1989). Outcrossing in peach. HortScience 24(2):359-360.

Nečas, T., L. Laňar, I. Ondrášek, J. Náměstek, J. Láčík, J. Kosina (2016). Propagation of Selected Pear and Quince Rootstocks by Hardwood Cuttings. ACTA UASMB. 64 (136): 1211-1217.

Pervez, M., M. Zubair, M. Saleem, K. Wali and M. Shah (2007). Effect of indole butyric acid (IBA) and planting times on the growth and rooting of peach cuttings. Sarhad J. Agric., 23 (3): 587-592 
Pregl, F. (1945). Quantitative Organic Micro Analysis. 4th ed. J. \& A. Churchill, L.T.D. London.

Rana, H. S. and T.R. Chadha (1992). Studies on the clonal propagation of Prunus species and their relationship with some biochemical characters. Progressive Hortic. 24, 329-335.

Reighard, G. and F. Loreti (2008): Rootstock development. p. 193-220. In: D.R. Layne and D. Bassi (eds.), The Peach: Botany, Production and Uses. CABI, UK.

Rufato, L., L.H. Buso, R. Trevisan, A. de Rossi, V.C. Guarda, E. Kersten and A. de Rossi (2000). Effect of flower buds on rooting of woody cuttings of peaches cv. BR2 treated with different concentrations of IBA. Revista Basileira Fruticultura, 22: 297-299.

SAS (1990): SAS/STAS User's Guide. 4th ed., Cary, SAS Institute Inc., pp. 891-1230.

Smith, P. F., M.A. Giller and P.A. Gesees (1956): Colorimetric methods for determination of sugar and related substances. Anal. Chem., 28:350.

Szecskó. N. and K. Hrotkó (2004): Propagation of Plum Rootstocks by Hardwood Cuttings. Acta Hort 658, ISHS: 673-677.
Szecskó, V., A. Csikos and K. Hrotko (2002). Timing of hardwood cuttings in the propagation of plum rootstocks. Acta Hort. 577:115-119.

Szecskó,V., K. Hrotkó and É. Stefanovits-Bányai (2007). Influence of Physiological Factors on Rooting Ability of Plum Rootstocks.Europ.J.Hort.Sci., 72 (4). S. 186192.

Tsipouridis C, T. Thomidis and A. Isaakidis (2003). Rooting of peach hardwood and semihardwood cuttings. Australian J. Exp. Agric. 43: $1363-1368$.

Tsipouridis $\mathrm{C}$, Thomidis $\mathrm{T}$ and $\mathrm{S}$. Bladenopoulou (2006). Seasonal variation in sprouting of GF 677 peach $\times$ almond (Prunus persica $\times$ Prunus amygdalus) hybrid root cuttings. New Zealand J. Crop and Hortic. Sci. 34: 45-50.

Wilson, P. J. and J. Van Staden (1990). Rhizocaline, rooting co-factors, and the concept of promoters and inhibitors of adventitious rooting - a review. Ann. Bot. 66, 476-490.

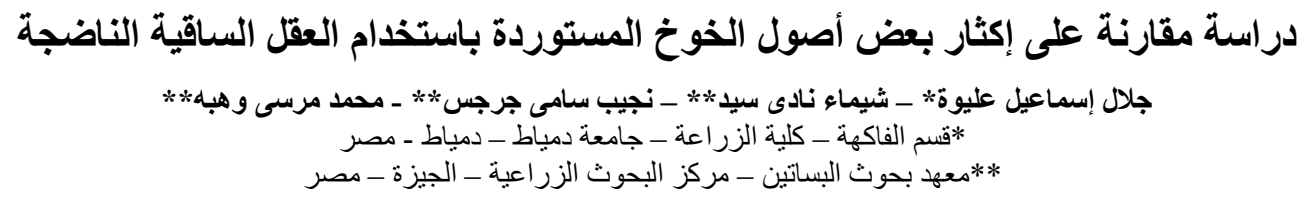

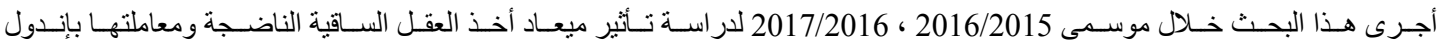

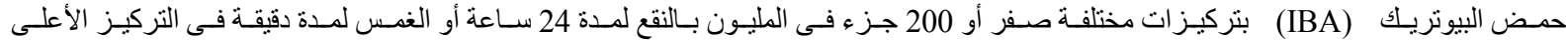

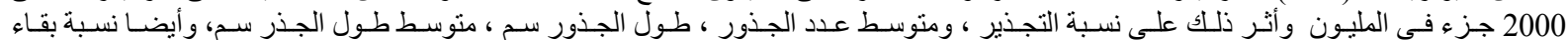

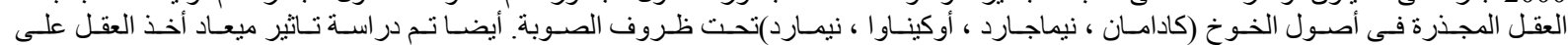

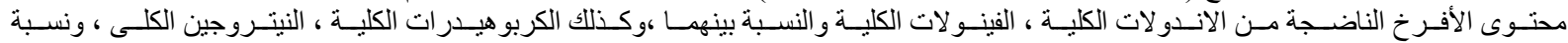

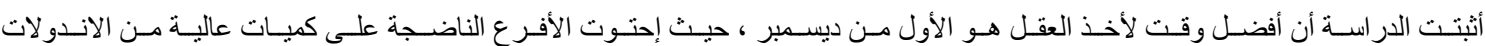

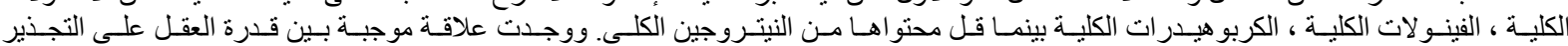

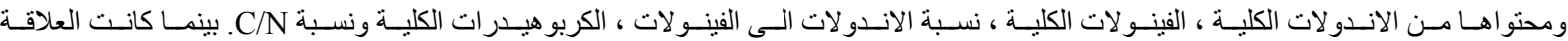

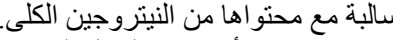

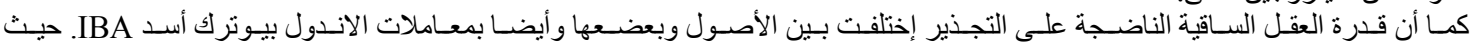

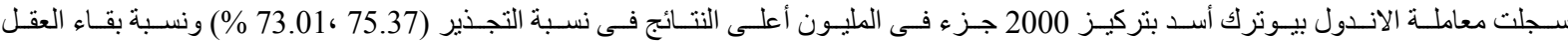

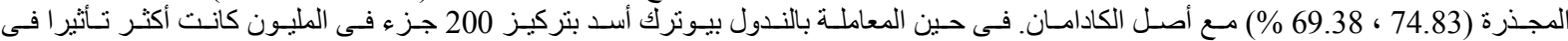

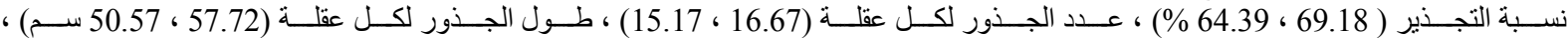

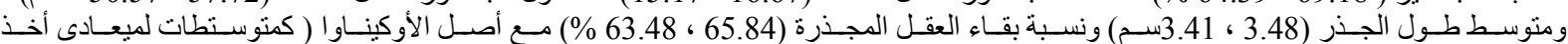

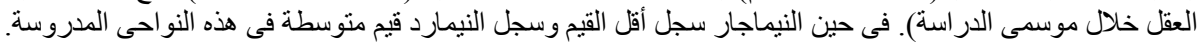

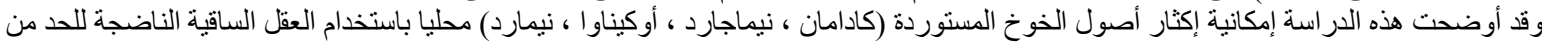
الاستير اد من الخارج وتوفير العملة الصعبة للبلاد. 